\title{
BUILDING COALITIONS: Coalition Goal Setting
}

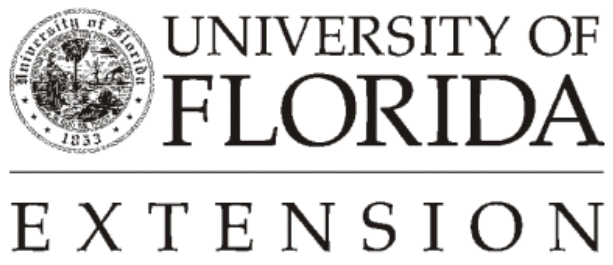

Institute of $\mathbf{F}_{\text {ood and }} \mathbf{A}_{\text {gricultural }} \mathbf{S}_{\text {ciences }}$ 


\section{Your Road Map To Success}

Before you start a trip, you may need a road map to tell you how to get to your destination. A coalition also should have a plan for how they want to meet their goals. This fact sheet will help develop your plan as a coalition to be successful.

This fact sheet will:

- $\quad$ Provide a process for coalitions to develop a course of action for establishing realistic goals/objectives.

- $\quad$ Provide a method to accomplish realistic goals set by the coalition.

\section{Characteristics of Goals}

It is important that members of the coalition keep certain characteristics in mind as they develop goals. As each is developed, put it to the test. Does it include the following characteristics?

Goals must be:

- Believable - They should describe situations or conditions that the coalition believes can be achieved. Avoid the "pie- in-the-sky" goals that members do not believe nor find possible to do.

- Attainable - It should be possible to do the goals in the designated time.

- Tangible - The goals should be capable of being understood or realized.

- On a Timetable - A completion date should be included in the goal statement.

- Win-Win - The goals must allow all members of the coalition to be successful.

After the goals have been established, allow the members to review them before they are written in final form. Input and acceptance is a vital ingredient to successfully accomplishing the group's goals.

\section{Establishing Coalition Goals}

By the time goal setting takes place, members or organizations should have already participated in a needs assessment. From this, the group:

- Develops a list of priorities (worksheet on brainstorming).

- Shares what problems or needs are being addressed by their agency/organization (individual goals). 
- Identifies group goals. Finds new problems to address and enhances present work on problems.

Group goals need to be a blend of individual goals. It is vital that all members of the coalition participate in goal development. This will:

- $\quad$ Help meet members' needs and interests.

- Show how individual action can lead to group goals.

- $\quad$ Stimulate cooperation and commitment.

It is important for all coalition members to:

- $\quad$ Allow each group member to keep their identity and specialties. Draw on each other's strengths.

- Not allow hidden agendas to jeopardize the work of the coaliton. Members should be honest, up-front and willing to modify their ideas for the goals of the coalition.

- $\quad$ Recognize everyone for their involvement. A coalition is a cooperative effort to address a problem and the same is true the recognition.

\section{Turning Goals into Action}

It is vital for the coalition members to write the group's goals. Goals that are in one's head are merely dreams, but written goals are a commitment.

Goals are turned into action by working from the long term to the short term. Decide what must be done and in what order. Next decide what will be done during a specific period. Design small, specific "bite-size" programs and activities that support the short-term goals. If order is important, decide a sequence for your activities. These questions will help:

- Where does the group want to be in one year? Six months?

- What "bite-size" programs or activities will move the coalition toward this position?

- What program or activity should be done at the next meeting?

\section{Summary}

The general goal of a coalition is the positive change in people and programs. By developing sound goals, the coalition will have a road map that will enable you to address issues of today and tomorrow. 


\section{Definitions}

These terms are important to understand as you work with coalition members to develop goals.

- Goal/Objective - A specific result desired in a certain amount of time.

- $\quad$ Short-Term Goal - Component to do over a short period. It also may lead to accomplishment of a long-term goal of the coalitions. Short-term goals may include the individual goals of the different organizations.

- $\quad$ Long-Term Goal - Component to do over a long period. The long-term goal should include the complete goals decided by the coalition.

- Group Goal - A goal determined by members of the coalition that will further the cause of the group. It is a blend of individual goals.

- Individual Goal - A goal determined by an individual coalition member that will be his or her contribution to the complete goal of the coalition.

\section{References}

Hartford, Margaret E. Groups in Social Work. New York: Columbia University Press, 1971.

\section{Hull, Lorie. Goal setting: Your Road Map to Success, Cassette Recording No.332. National Press Publications, Inc.}

\section{(C) 1992 The Ohio State University}

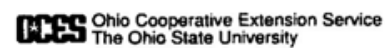

This series on Coalition Building was developed by The Ohio Center For Action on Coalition Development for Family and High Risk Youth, Richard Clark, Ph.D., Director. It has been adapted for County Extension Faculty in Florida to facilitate work with local and regional organizations and groups such as non-profits, cooperatives, county extension associations, and others that might benefit from a plan for working together to achieve support for mutual goals.

This document is FY496, Part 4 of the 16 part series adapted for use in Florida by Elizabeth B. Bolton, Professor, Community Development and Lisa Guion, Assistant Professor, Program Planning and Evaluation; Department of Family, Youth and Community Sciences, Florida Cooperative Extension Service, Institute of Food and Agricultural Sciences, University of Florida, Gainesville, 32611-0310.

Reprinted with permission March, 1997. Revised April, 2002.

The Institute of Food and Agricultural Sciences is an equal opportunity/affirmative action employer authorized to provide research, educational information and other services only to individuals and institutions that function without regard to race, color, sex, age, handicap, or national origin. For information on obtaining other extension publications, contact your county Cooperative Extension Service office.

Florida Cooperative Extension Service/Institute of Food and Agricultural Sciences/University of Florida/Christine Taylor Waddill, Dean 